\title{
Solar PV power driven cold room storage for Saharan rural area
}

\author{
Mouloud.Tizzaoui ${ }^{1 *}$, Hamou Soualmi ${ }^{1}$ Mohamed Allaoui ${ }^{1}$, Achor Mansouri ${ }^{1}$, Zine Saadi ${ }^{1}$, Dalila Menacer ${ }^{1}$, Samir $_{\text {Chadli }}{ }^{1}$ \\ ${ }^{1}$ Unité de Recherche en Energies Renouvelables en Milieu Saharien, URERMS, Centre de Développement des Energies Renouvelables, \\ CDER, 01000, Adrar, Algeria
}

\begin{abstract}
The use of renewable energy sources is usually a reliable alternative in rural areas and developing countries, where the gridline does not exist or is at a great distance. The present work is to study the possibility of feeding the tomatoes preservation cold room storage in the Sahara region driven by solar photovoltaic generator. An energy-efficient design has been achieved by analytical calculation. A PV field calculation approach yielded the following results: for a storage capacity of about 1 ton of tomatoes, the cooling capacity is $2.5 \mathrm{~kW}$. The use of the design unit gave us in terms of electricity requirements 27 $\mathrm{kWh} /$ day by the GPV generator at Adrar province. Electrical power demands can be obtained using an alternative solution, which appears in Vapor Compression Cycles driven by PV modules. This technology considered as promoting concept for the south of Algeria investment.
\end{abstract}

\section{Introduction}

From a long time ago, human beings have been well aware of the benefits of cold usage as a way to preserve food. The use of the cooling process exists in several areas among them we can found: the food industries, medicine, air conditioning, petrochemicals, etc. Cold generated on food storage is frequently achieved by applying a compression cycle of a refrigerant fluid. It is commonly observed that refrigeration systems are responsible for a large amount of electric energy consumption. Many people in remote and rural areas in the developing countries are unable to access electricity from the grid. Moreover, Adrar province is predominantly an agricultural country with more than $70 \%$ of the population is living in rural areas living in agriculture. Some perishable vegetables like tomato's need for developing a storing facility for a short period (1 to 2 weeks) may help the farmers to supply their produced goods at a constant pace. In the Saharan Environment, refrigeration for the preservation of food products, especially in summer, is often responsible for a sharp peak in electrical power consumption, which is around a third of total consumption. Considering that cooling demand increases with the intensity of solar radiation, solar cooling is considered as an alternative solution. Figure1 summarized the different technologies that are available to deliver cooling from solar energy [1]. Solar PV cooling technology is a process that produced an electric power by the photovoltaic (PV) system. This energy driven to power a conventional vapor compression refrigeration cycle. As shown in Figure 1, solar electric PV panels have been proposed for several decades. Solar PV cooling was limited by low PV efficiency and high initial investment and its application has been ignored until recent years [2-3]. Because of the

\footnotetext{
*Corresponding author: m.tizaoui@urerms.dz
}

sharp fall down of PV module price, the initial investment of PV air conditioner (PVAC) decreased as well, advantages of PVAC stand out among different kinds of solar cooling and more attention has been paid to PVAC. Some experimental results and practical data proved that PVAC has the merits of high performance, electricity-saving, stable and reliable operation [4-5].

The simplest way to utilize solar energy for cooling involves connecting a conventional vapor compression chiller to a PV power supply system. Individual solar cooling technologies are described below. A vapor compression chiller driven by direct current generated by PV modules is a relatively simple solution, but it requires using a battery. This limits the size and rating of such a system. As a result, this technology is used mainly in small-scale applications, often in portable devices used to store medicines or food. Figure 2 shows a schematic of a vapor compression chiller driven by electricity generated by PV modules [6]. This electricity is used to power a direct current motor that drives the chiller compressor. The cycle of the refrigerant is a typical cycle of a vapor compression chiller. The chiller shown in Fig. 2 contains no battery. A battery with a solar charge controller may be placed between the PV modules and the motor. Such a solution enables charging the battery and consuming electricity by the compressor at the same time and enables the operation of the compressor motor at steady power supply parameters. If a vapor-compression chiller is an alternating currentdriven design, then an inverter needs to be placed after the battery to convert direct current into alternating current. An alternating current chiller may also be powered directly from a power grid during periods when no solar radiation is available or when irradiance is too low to be used effectively. In this case, no battery is needed. The Adrar province is considered an advantage 


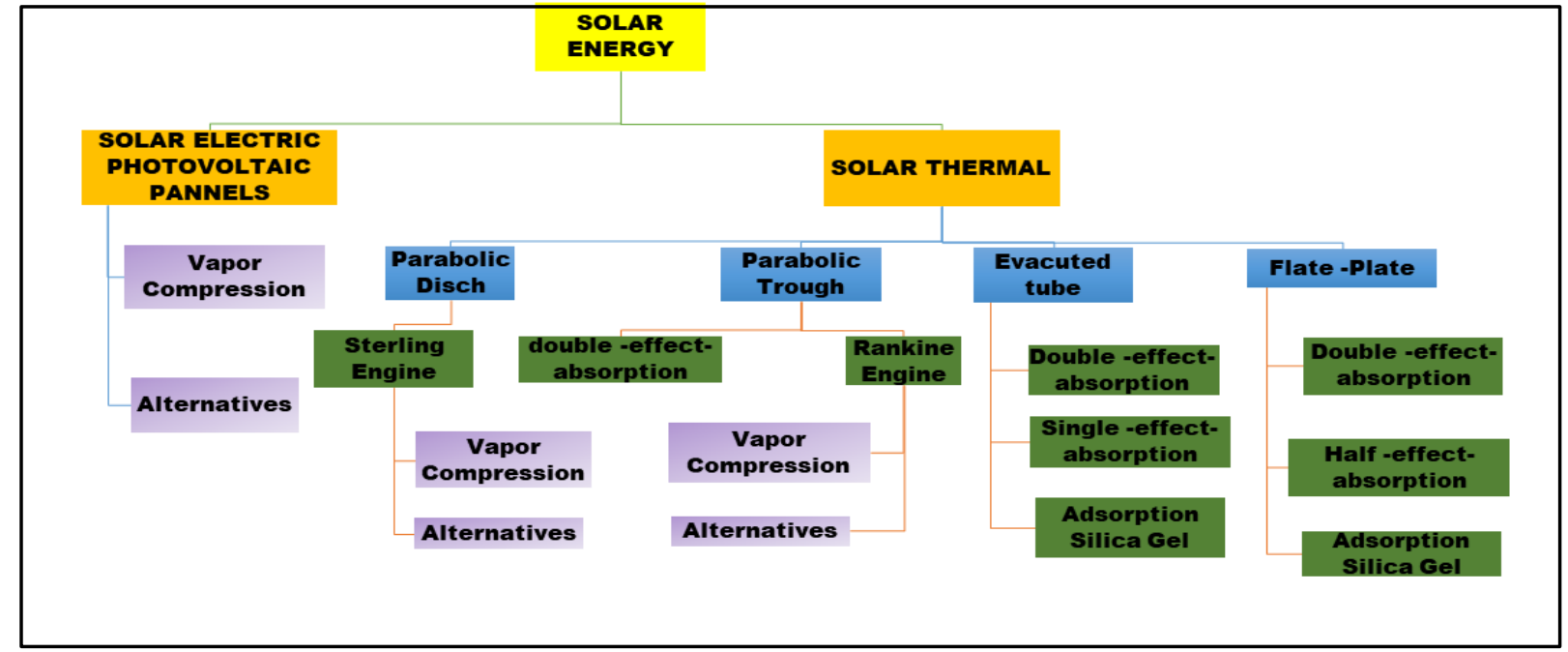

Fig.1. Alternative routes from solar energy into cooling effect using thermodynamic cycles [1]

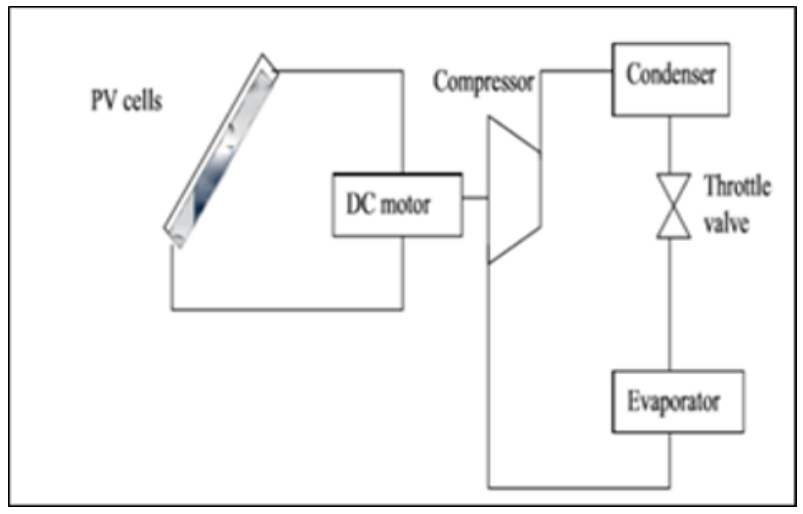

Fig. 2. Schematic of a PV-driven vapor Compression chiller

[6].

site over the world, which spreads each year on a large hot and dry period. This often coincides with high solar radiation [7]. For this purpose, our study focuses on integrating the concept of sustainable development by applying solar photovoltaic driven electricity for cooling storage uses located in the Saharan environment. In this report, we are presenting a study on Solar PV based cold storage operating with a vapor compression-refrigeration cycle under hot summer conditions for the off-grid areas of Adrar province. This paper based on an analytical strategy that determines all energetic components

\subsection{Geographic location}

Adrar town is located in the southwestern of the Algiers capital. This region of the Algerian desert is a part of the gigantic northern African Sahara and is characterized by a hot continental climate. This climate has only two seasons in the year: summer and winter. The winter season is short include only December until March. Nevertheless, the summer season is much too long and spread from May until November. July considered a critical month compared to others. The maximal temperature is very high and the measured ambient temperatures exceed more than $50^{\circ} \mathrm{C}$. According to the data of the station [8], the maximum outside temperature of the ambient air taken for the optimization of the loads is of the order of $50^{\circ} \mathrm{C}$ (at the base of the hottest day of the year) and a humidity of $\mathrm{RH} 11 \%$ and an average daily radiation of $6.553\left(\mathrm{KWh} / \mathrm{m}^{2} /\right.$ day $)$.
- Understand the geographical location of the installation and the climatic conditions of the city of Adrar illustrated in the following table.

- The cold room to be tested is a modular manufacture with sandwich polyurethane panels. It is a single warehouse oriented North-South, East-West and located in the URER-MS at Adrar, latitude $28^{\circ}$ North, longitude $-0.2^{\circ}$ West and altitude $276 \mathrm{~m}$.

- The cold room is located in a very hot and dry climate region.

Table 1. Data ener Mena high precision meteorological station in Adrar, Algeria [8].

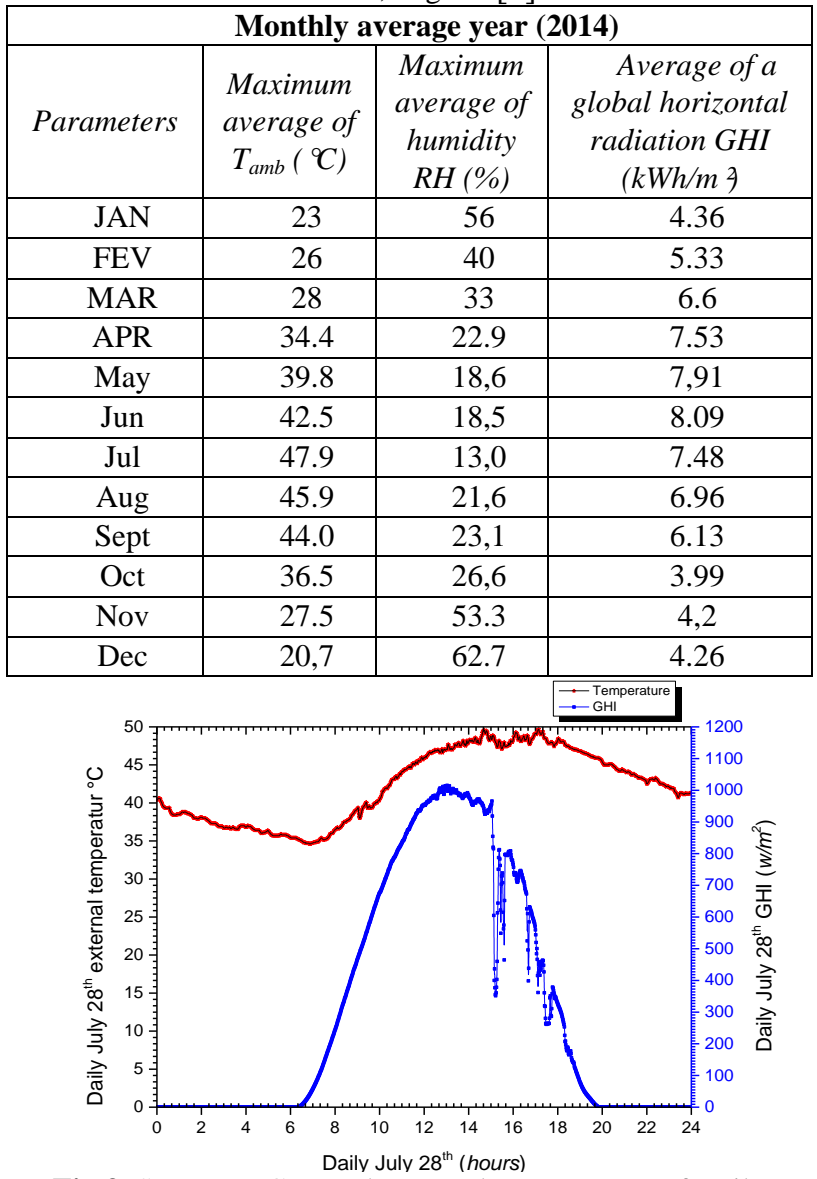

Fig.3. Summary GHI and External Temperature of Daily July $^{28 \text { th }}[8]$. 
For the calculation balance sheet, July $28^{\text {th }}, 2014$ is selected as a hottest critical day. As shown in (Figure 3), the average external temperature is about $47^{\circ} \mathrm{C}$ and the global radiation can reach over $1013(\mathrm{w} / \mathrm{m} 2)$ at 1:00.p.m. The beginning of the electric power production of PV modules above 8:00.mornning and finishing at 18:00, afternoon, which means 10 hours of effective sun time.

\section{Design steps}

The methodology to estimate energy requirements for the cold room storage, the following items are considered in the design steps of the cold storage:

- Calculate the size of the cooling system

- Electrical energy required for the cooling system

- $\quad$ Size of the solar PV field.

Selected parameters for this analysis and all relevant initial considerations described in Table 2

\subsection{Thermal loads calculation}

The thermal study makes it possible to determine the cooling capacity of the conservation unit. For the supply of the storage enclosure, it is essential to establish a refrigeration thermal balance. In this context, it is a question of making the inventory of the quantities of heat to be extracted from inside a cold room, to maintain the constant temperature of the products. These known's basic data, we can then proceed to the exhaustive determination of the charges against which the cooling unit will have to fight. All existing thermal loads can be classified into two main categories, according to their origin: internal and external. Figure 4 discriminates and classifies all of them, as documented in [9].



Fig. 4. Classification of thermal loads existing in cold chambers [9].

\subsubsection{Total sensitive intermediate thermal loads}

The sum of intermediate sensitive loads presented in figure.4, expressed as:

$$
\begin{aligned}
& Q_{\text {thermal,load }}=Q_{\text {trs,total,wall }}+Q_{\text {air }}+\left(Q_{\text {elc }}+\right. \\
& \left.Q_{\text {pers }}+Q_{\text {machine }}\right)_{\text {others,load }}+\left(Q_{\text {temp,red }}+\right. \\
& \left.Q_{\text {respiration }}\right)_{\text {products,load }}
\end{aligned}
$$

From the calculation based in ref [10] and According to the input parameters described in table 2 . Then again, the formula (1) will written as function of thickness insulation of wall and temperature for the sum of loads:

$$
\begin{aligned}
Q_{\text {Total, loads }}= & \left(\frac{0.7452}{0.09+\frac{e_{i}}{0.029}}\right)+0.00072 e_{i}+ \\
& 1.24 \quad(K W)
\end{aligned}
$$

\begin{tabular}{|c|c|c|}
\hline \multirow{3}{*}{$\begin{array}{l}\text { Constructive } \\
\text { aspects }\end{array}$} & Dimension of room & Length: $L=2(m) ;$ Width $l=1,5 m ;$ Height $\mathrm{H}=2,5 m ;$ Volume $V=7,5 \mathrm{~m}^{3}$ \\
\hline & \multirow[t]{2}{*}{ Insulation material } & Material type: ALL walls of Foam sandwich panels in expanded Polyurethane; \\
\hline & & Conductivity $\lambda=0.029\left(\mathrm{~W} / \mathrm{m}^{\circ} \mathrm{C}\right) ; \quad$ Thickness insulation $e=0.12(\mathrm{~m})$; \\
\hline \multirow{19}{*}{$\begin{array}{l}\text { Climactic } \\
\text { variables }\end{array}$} & \multirow[t]{8}{*}{ External parameters } & External air temperature: $T_{e x t}=50^{\circ} \mathrm{C}$ \\
\hline & & Outside Relative humidity: $H R=11 \%$; \\
\hline & & Outside Enthalpy air: $h_{\text {entpi }}=72.42(\mathrm{~kJ} / \mathrm{kg})$ \\
\hline & & Ground temperature: $T_{S o l}=38\left({ }^{\circ} \mathrm{C}\right)$ \\
\hline & & $\begin{array}{l}\text { Temperature Increase by solar radiation of the vertical walls: } \\
\Delta T_{E}^{\prime}=\Delta T^{\prime}{ }_{O}=3.7^{\circ} \mathrm{C} ; \Delta T_{N}^{\prime}=\Delta T_{S}^{\prime}=1.9^{\circ} \mathrm{C} \text {; }\end{array}$ \\
\hline & & Temperature Increase by solar radiation of the floor $T_{P F}^{\prime}=7.4\left({ }^{\circ} \mathrm{C}\right)$ \\
\hline & & External convective exchange coefficient $h_{e x t}=30\left(\mathrm{~W} / \mathrm{m}^{2} . \mathrm{K}\right)$ \\
\hline & & Density of the air around the room $\rho_{e x t}=1.24\left(\mathrm{~kg} / \mathrm{m}^{3}\right)$ \\
\hline & \multirow{6}{*}{$\begin{array}{l}\text { Internal parameters } \\
\text { of air }\end{array}$} & Internal cooling room temperature $T_{C F}=\left(12^{\circ}\right)$; \\
\hline & & Indoor Relative humidity $H R=90 \%$; \\
\hline & & Indoor Enthalpy air: $h_{\text {entpi,int }}=31.88(\mathrm{~kJ} / \mathrm{kg})$; \\
\hline & & Density of the air in the room: $\rho_{C F}=1.24\left(\mathrm{~kg} / \mathrm{m}^{3}\right)$ \\
\hline & & Air renewal rate $n \cong 12$ \\
\hline & & Internal convective exchange coefficient $h_{\text {int }}=16\left(\mathrm{~W} / \mathrm{m}^{2} . \mathrm{K}\right)$; \\
\hline & \multirow{5}{*}{$\begin{array}{l}\text { Internal parameters } \\
\text { of Products }\end{array}$} & Ground occupancy coefficient of products: $\eta_{o c}=0.65$ \\
\hline & & Total room capacity of storage: $C_{C F}=1117(\mathrm{~kg})$ \\
\hline & & Heat capacity before freezing Tomato: $C_{p a v}=3.98(\mathrm{~kJ} / \mathrm{kg} . \mathrm{k})$ \\
\hline & & Tomato temperature: $T_{\text {product }}=33^{\circ} \mathrm{C}$ \\
\hline & & Heat respiration of tomato: $q_{\text {resp }}=3.47($ W/tonn $)$ \\
\hline
\end{tabular}

Table 2. Initial parameters consideration 
The choice of insulation thickness value $\mathrm{e}=0.12 \mathrm{~m}$ and setting the other parameters described in Table 2. Then, only the external temperature set as variable value. Therefore, equation will written in this form:

$$
Q_{\text {Total,loads }}=1174+5 T_{\text {air,ext }} \quad(\text { Watt })
$$

\subsection{The GPV calculation}

Given that the maximum electrical power absorbed as well as the different voltages and intensities at the terminals of each component are obtained, we can start sizing the generating part of the photovoltaic field to know the daily need in energy for the operation of the cold room. It should be noted that for the sizing of solar panels, it is better to reason in energy and not in power. The energy absorbed by the installation depends not only on the power required by the devices but also on the duration and frequency of use. It is expressed in watthours $(W h)$ for a given period (by day, month or year). Our food unit preservation will have to operate 16 hours per day. The daily energy absorbed expressed as:

$E_{\text {absorbed }}=W_{\text {power; } \text { cooling unit }} * t_{\text {operating,max }}$

With the maximum time of compressor working:

$t_{\text {operating, } \max }=16 h$

To calculate the characteristics of the photovoltaic generator system in real climatic conditions, we use the average global radiation during the month of JULY 2017 of the Mini Power GPV station located at URER/MSAdrar, which estimated about of

$H_{G P V, \beta=28^{\circ}}=6.566\left(\mathrm{kwh} / \mathrm{m}^{2} /\right.$ day

The characteristics of the photovoltaic modules given according to the international standardization namely (STC): - Solar radiation of $1 \mathrm{~kW} / \mathrm{m}^{2}$,

- An internal temperature of the cells or an ambient temperature of $25^{\circ} \mathrm{C}$,

- $\quad$ an AM 1.5 radiation spectrum

The most important electrical characteristics of a photovoltaic module are the short circuit current, the open-circuit voltage and the maximum operating point depending on the radiation and the temperature of the place. These characteristics given in tables or diagrams by the manufacturers however in general an update is necessary. Our choice is for a module with the following specifications:

Table 3. PV module specification.

\begin{tabular}{|c|c|}
\hline \multicolumn{2}{|c|}{ PV Module } \\
\hline Parameter & Specification \\
\hline Type of module & Mono-Crystalline \\
\hline Rated Power at STC (Pmax) & $250 \mathrm{~W}$ \\
\hline Max. Power Voltage (Vmp) & $30.75 \mathrm{~V}$ \\
\hline Max. Power Current (Imp) & $8.131 \mathrm{~A}$ \\
\hline Open Circuit Voltage (Voc) & $36.99 \mathrm{~V}$ \\
\hline Short Circuit Current (Isc) & $8.768 \mathrm{~A}$ \\
\hline Efficiency & $15.3 \%$ \\
\hline Dimension & $990^{*} 165^{*} 40 \mathrm{~mm}$ \\
\hline Weight & $19.5 \mathrm{~kg}$ \\
\hline Nominal Operating Cell Temp & $+48 \mathrm{C}^{\circ}$ \\
\hline Maximum System Voltage & $1.000 \mathrm{~V}$ \\
\hline Operation Temperature & -40 to +90 \\
\hline
\end{tabular}

\subsubsection{Power estimation of the GPV}

The peak power of the photovoltaic generator depends on the daily irradiation of place, the daily electrical energy requirement of the installation that the PV generator will produce and conversion losses. The following formula give the power estimation:

$P_{G P V}=\frac{E_{\text {daily;requirement }}}{H_{G P V, \beta=28^{\circ} \cdot R_{C P}}}$

With:

$\boldsymbol{R} \boldsymbol{c p}=0.65$ : Loss coefficient of electrical conversion process;

$\boldsymbol{E}_{\text {daily }}$ : The daily electrical requirement that the

GPV will produce;

In any case, the average power delivered by a module is still much lower than its nominal power, because even the nominal conditions of international standards are very optimistic compared to real situations. In real condition, an estimation of the electrical energy of module $\boldsymbol{E}_{\text {daily,mod }}$ equal to the product of the nominal power at STC condition by the number hours of solar equivalent time $N_{h}$ (Duration of Sunshine). This translates to the following formula:

$P_{\text {real }, \text { mod }}=\frac{E_{\text {daily,mod }}}{H_{G P V, \beta=28^{\circ} \cdot R_{C P}}}=\frac{P_{\text {nom }, \text { mod }} \cdot N_{\text {hours }}}{H_{G P V, \beta=28^{\circ} \cdot R_{C P}}}$

With:

$P_{\text {real, mod: }}$ Real power of the modules;

$P_{\text {nom, mod: }}$ nominal power of STC condition modules;

$E_{\text {daily,mod: }}$ produced energy of a module;

$\mathrm{N}_{\text {hours }}$ : Number of equivalent hours of sunshine (in case of Adrar city, knowing that during the month of July, the equivalent time effective of reception of the modules is ( $N_{\text {hours }}=10$ hours);

\subsubsection{Approximation the total number of modules.}

The total number of photovoltaic modules is calculated by relating the overall peak power of the GPV field to that of a single unit module $P_{\text {real,mod }}$. The installation will receive radiation for 10 hours; we can estimate the number of modules required by the installation:

$N T P I=\frac{P_{G P V, \text { feild }}}{P_{\text {real }, \text { mod }}}$

\subsubsection{The number of modules in series.}

The number of modules connected in series Ns depends on the voltage of the installation via the converters. It is expressed by the rate of the nominal DC input voltage of the inverter $\left(V_{e c}\right)$ and the nominal voltage of the module $\left(V_{n}\right)$ :

$$
N_{s}=\frac{V_{e c}}{V_{n}}
$$

\subsubsection{Choice of Inverter.}

Our choice is for a SOLARGIE brand inverter with the characteristics listed in table 4 . 
Table 4. SMA Smc 11000tlrp-10 Inverter Specification

\begin{tabular}{|c|c|}
\hline \multicolumn{2}{|l|}{ Inverter } \\
\hline Parameters & Specification \\
\hline \multicolumn{2}{|l|}{ Input(DC) } \\
\hline Max. DC Power & $11400 \mathrm{~W}$ \\
\hline Max. input voltage & $700 \mathrm{~V}$ \\
\hline Mpp voltage range & $333 \mathrm{~V}-500 \mathrm{~V} / 350 \mathrm{~V}$ \\
\hline Max. input voltage & $333 \mathrm{~V} / 400 \mathrm{~V}$ \\
\hline Max. input current & $34 \mathrm{~A}$ \\
\hline \multicolumn{2}{|l|}{ Output(AC) } \\
\hline Rated power(@230v,50hz) & $11000 \mathrm{VA}$ \\
\hline Max. apparent AC power & 11000VA \\
\hline Nominal AC Voltage / range & $\begin{array}{l}220 \mathrm{~V}, 230 \mathrm{~V}, 240 \mathrm{~V} / \\
180 \mathrm{~V}-265 \mathrm{~V}\end{array}$ \\
\hline $\mathrm{AC}$ power frequency / range & $\begin{array}{l}50 \mathrm{~Hz}, \quad 60 \mathrm{~Hz} /- \\
6 \mathrm{~Hz} \ldots+5 \mathrm{~Hz}\end{array}$ \\
\hline $\begin{array}{l}\text { Rated grid frequency / rated grid } \\
\text { voltage }\end{array}$ & $50 \mathrm{~Hz} / 230 \mathrm{~Hz}$ \\
\hline Max. output current & $48 \mathrm{~A}$ \\
\hline \multicolumn{2}{|l|}{ Efficiency } \\
\hline $\begin{array}{l}\text { Max. efficiency / } \\
\text { European Efficiency }\end{array}$ & $\begin{array}{l}97.7 \% / \\
97.2 \%\end{array}$ \\
\hline
\end{tabular}

\subsubsection{The number of branches in parallel}

Branch is defined as the number of modules connected in series. To have the total current that the installation will need to operate, we will have to connect branches in parallel. The number of branches (modules in parallel) given by the equation:

$N_{p}=I N T\left[F_{S}\left(\frac{E_{\text {daily }}}{H_{G P V, \beta=28^{\circ} \cdot n_{m} \cdot n_{c} \cdot S_{c e l} \cdot N_{S}}}\right)\right]$

With:

INT: Entire part of parenthetical expression

$\mathrm{F}_{\mathrm{S}}$ : Safety factor generally taken equal to 1.1

$\mathrm{S}_{\mathrm{cel}}$ : Surface of a module;

$\eta_{\mathrm{m}}$ : Module efficiency;

$\eta_{\mathrm{c}}$ : Converter efficiency;

\section{Results and Discussions}

The need for some optimizations to reduce the sum of the loads must result:

- At least technical-economic analysis by playing on the insulating quality of the walls;

- Economic choice of the refrigeration unit;

- Provide cooling capacity via a PV supply;

\subsection{Evaporative cooling capacity}

The provisional determination of the number and type of evaporator for the installation, based on the calculation of the predicted cooling capacity, which is obtained by adding $20 \%$ of security. We then:

$$
\begin{aligned}
& W_{\text {power,predicted }}=1.2\left(\frac{W_{\text {predicted }, \text { cooling capacity }}}{t_{\text {operting, } \text { max }}}\right) \\
& W_{\text {power,predicted }}=1.2\left(\frac{Q_{\text {totale, }, \text { sensetive loads } .24}}{t_{\text {operting, } \text { max }}}\right)
\end{aligned}
$$

- The cooling capacity must make it possible to compensate for all the foreseeable operating balances of a cold room in a maximum time, $t_{\max }$ (in seconds), imposed by the operator to respect certain technical or financial constraints. The capacity of cooling provided in this study according to the thermal loads of our unit preservation is committed as crucial data for the determination of the power balance sheet and the design of an optimal selection of condensation unit. For $t_{\max }=16$ hours, then

$$
W_{\text {power,predicted }}=2.5
$$

\subsection{Cooling time}

Regardless the sensible thermal loads balance, the daily cooling time of tomato, is expressed as:

$$
\begin{aligned}
& t_{\text {cooling }}=1.2 \times 86400\left(\frac{Q_{\text {totale,sensetive loads }}}{W_{\text {power,predicted }}-W_{\text {power,Fan }}}\right)< \\
& t_{\text {max }} \\
& \text { Were, } \\
& W_{\text {power,Fan }} \text { The electric power of fan evaporator; }
\end{aligned}
$$

According to the equation (3), the cooling time of tomato in function outside temperature is written as follows:

$t_{\text {cooling }}=\left(\frac{121720.32+518.4 T_{\text {air }, \text { ext }}}{W_{\text {power, }, \text { predicted }}-W_{\text {power }, \text { Fan }}}\right)($ seconds $)$

(Figure. 5) indicates that in Saharan Environment of the daily July $28^{\text {th }}$, the sunshine effective time for the electrical power of the PV module (Duration of Sunshine) is 10 hours from 8:00 AM up to 6:00 PM. In this time, the cooling capacity can be provided by the PV field. Only 6 hours remain on the maximum operating time of the vapor compressor chiller to be ensured by the batteries. During the day, the compressor has downtime when the set cooling temperature is reached. In this case, the compressor is in a steady - state and no electrical power required. Nevertheless, to reduce the temperature of the tomato (removal of sensitive heat), the compressor working in the transient state until the set preservation temperature of product is established.

The time of cooling capacity is estimated according to equation (18). We noted that in our study, the cooling capacity is about $2.5 \mathrm{~kW}$ and the corresponding time cooling of tomato is about $46 \mathrm{~min}$ to reach the set point of $12^{\circ} \mathrm{C}$.

\subsection{Balance of GPV parameter}

The maximum electrical power that the installation will have to absorb is of the order:

$$
W_{\text {power, absorbed }}=1.7 \mathrm{~kW}
$$

From this data and previously parameters, it is possible to start the sizing of the GPV field.

The table. 5 summarize the photovoltaic power driven electric energy that cold room storage needed in daily operation. 


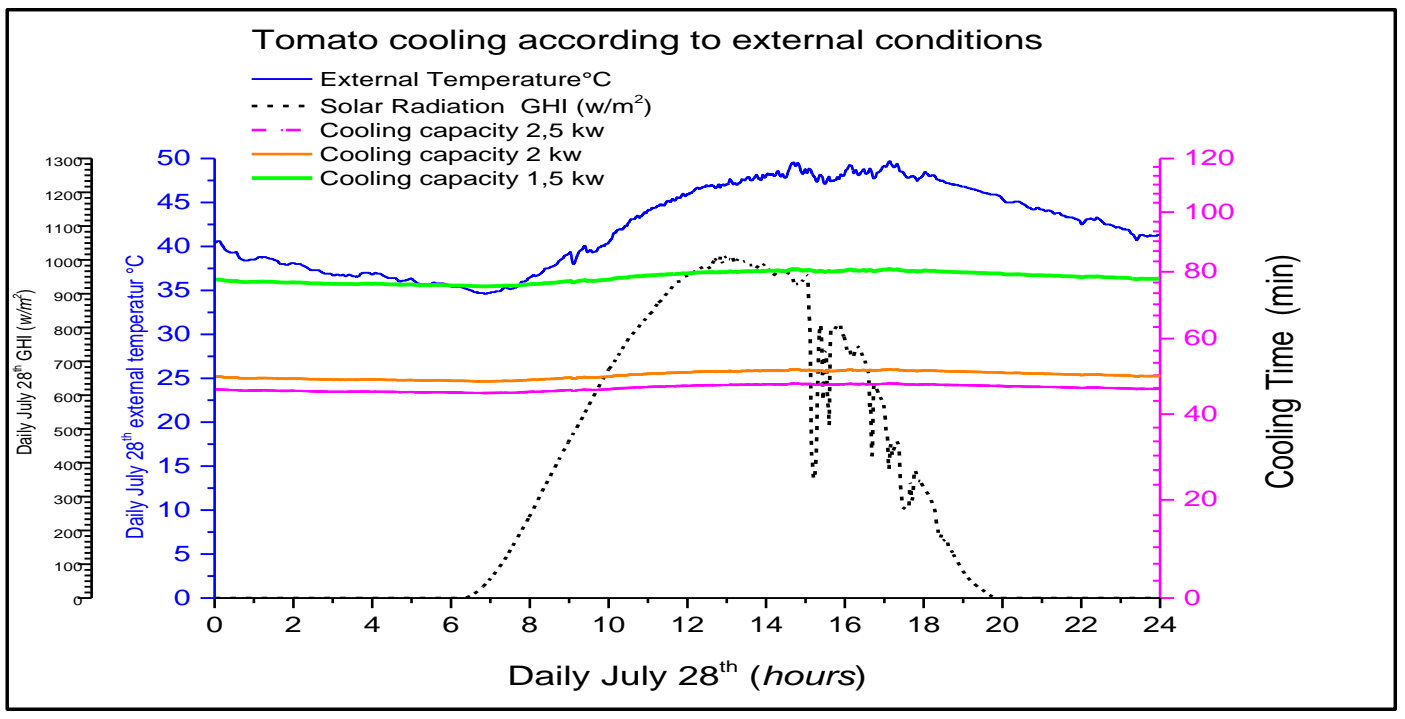

Fig. 5. Tomato cooling time by external condition.

Table 5. The GPV parameters summary.

\begin{tabular}{|l|l|}
\hline GPV Parameters description & Value \\
\hline $\begin{array}{l}\text { Power electric energy of the cooling } \\
\text { unit } W_{\text {power, absorbed }}\end{array}$ & $1.70(\mathrm{kw})$ \\
\hline $\begin{array}{l}\text { Daily electrical energy requirement } \\
E_{\text {daily;requirement }}\end{array}$ & $27.5(\mathrm{kWh})$ \\
\hline $\begin{array}{l}\text { Average global radiation energy of the } \\
\text { GPV per 1 meter surface consideration } \\
H_{G P V, \beta=28^{\circ}}\end{array}$ & $\begin{array}{l}6.566 \\
\left(\mathrm{kWh} / \mathrm{m}^{2} / \text { day }\right)\end{array}$ \\
\hline $\begin{array}{l}\text { Nominal power at STC condition } \\
P_{\text {nom,mod }}\end{array}$ & $250(\mathrm{wc})$ \\
\hline Real power of the module $P_{\text {real, mod }}$ & $0.585(\mathrm{KWc} /$ da $)$ \\
\hline $\begin{array}{l}\text { Daily Produced Energy of a modules } \\
E_{\text {dailv,mod }}\end{array}$ & $6.45(\mathrm{KWc} /$ day $)$ \\
\hline $\begin{array}{l}\text { Number equivalent hours of sunshine } \\
\text { (Duration Sunshine) } \mathrm{N}_{\text {hours }}\end{array}$ & $10(\mathrm{~h})$ \\
\hline Total number of modules & 8 \\
\hline Number of Modules in Series & 8 \\
\hline Number of Branches in Parallel & 1 \\
\hline Surface area of the GPV Feild $\mathrm{S}_{\mathrm{GPV}}$ & $13\left(\mathrm{~m}^{2}\right)$ \\
\hline
\end{tabular}

the electric consumption in hot season. The strategy on integrating GPV supply energy is less used regardless their required investments for specific applications in developing county like Algeria.

\section{References}

1. Chan, H.-Y., Riffat, S.B., Zhu, J., (2010). Review of passive solar heating and cooling technologies. Renew. Sust. Energ. Rev. 14,781.

2. A. Elsafty, A.J. Al-Daini, (2002) Economical comparison between a solar-powered vapour absorption Air-conditioning system and a vapour compression system in the Middle East, Renewable Energy. 25,569-583.

3. R. M. Lazzarin, (2014) Solar cooling PV or thermal? A thermodynamic and economical analysis, International Journal Refrigeration. 39, 38-47.

\section{Conclusion}

In this work, we analyze a PV based solar energy system used to generate electricity for locations where the grid is unreachable or the access is expensive. The aimed object is to integrating this concept in cold storage under Saharan rural regions. The example of a study is the defy to keep tomato temperature at a set point of $12^{\circ} \mathrm{C}$ in a hot and dry climate of Adrar province. Therefore, an optimal cold storage room design taking account of all parameters is required. The calculation methodology conducted analytically to present both the thermal balance sheet and the GPV field. The summarize result show for cooling capacity value of $2.5 \mathrm{kw}$, the daily energy electric requirement about $27 \mathrm{kwh}$ obtained from a PV supply which estimated to connect 8 modules in series. In this, system we need inverter, charge-controller and batteries for off-grid situation. In the case of Saharan environment and for local investment development, vapor compression cycles driven by PV power solar energy appear to be the alternative solution in view with

4. Y. Li, G. Zhang, G. Z. Lv, A. N. Zhang, R. Z. Wang, (2015) Performance study of a solar photovoltaic air conditioner in the hot summer and cold winter zone, Solar Energy. 117, 167-179.

5. F. J. Aguilar, P. V. Quiles, S. Aledo, (2014) Operation and Energy Efficiency of a Hybrid Air Conditioner Simultaneously Connected to the Grid and to Photovoltaic Panels, Energy Procedia. 48, 768-777.

6. Kima DS, Infante Ferreira CA, (2008) solar refrigeration options - a state-of-the-art review. Int $J$ Refrig; 31:3-15.

7. World Energy Council, /www.worldenergy.org;

8. EnerMena High Precision Meteorological Station in Adrar, Algeria-(2014).

9. American society of heating, Refrigerating and airconditioning engineers: handbook-refrigeration (2010).

10. H.J. Breidert, Ed., "Calclul des chamber froides" Edition PYC LIVRES, Paris, France, (1998). 